\title{
Interhemispheric leakage of isotopically heavy nitrate in the eastern tropical Pacific during the last glacial period
}

\author{
Laetitia E. Pichevin, ${ }^{1}$ Raja S. Ganeshram, ${ }^{1}$ Stephen Francavilla, ${ }^{1}$ Elsa Arellano-Torres, ${ }^{1}$ \\ Tom F. Pedersen, ${ }^{2}$ and Luc Beaufort ${ }^{3}$ \\ Received 18 February 2009; revised 19 August 2009; accepted 5 October 2009; published 2 February 2010.
}

[1] We present new high-resolution $\mathrm{N}$ isotope records from the Gulf of Tehuantepec and the Nicaragua Basin spanning the last 50-70 ka. The Tehuantepec site is situated within the core of the north subtropical denitrification zone while the Nicaragua site is at the southern boundary. The $\delta^{15} \mathrm{~N}$ record from Nicaragua shows an "Antarctic" timing similar to denitrification changes observed off Peru-Chile but is radically different from the northern records. We attribute this to the leakage of isotopically heavy nitrate from the South Pacific oxygen minimum zone (OMZ) into the Nicaragua Basin. The Nicaragua record leads the other eastern tropical North Pacific (ETNP) records by about 1000 years because denitrification peaks in the eastern tropical South Pacific (ETSP) before denitrification starts to increase in the Northern Hemisphere OMZ, i.e., during warming episodes in Antarctica. We find that the influence of the heavy nitrate leakage from the ETSP is still noticeable, although attenuated, in the Gulf of Tehuantepec record, particularly at the end of the Heinrich events, and tends to alter the recording of millennial timescale denitrification changes in the ETNP. This implies (1) that sedimentary $\delta^{15} \mathrm{~N}$ records from the southern parts of the ETNP cannot be used straightforwardly as a proxy for local denitrification and (2) that denitrification history in the ETNP, like in the Arabian Sea, is synchronous with Greenland temperature changes. These observations reinforce the conclusion that on millennial timescales during the last ice age, denitrification in the ETNP is strongly influenced by climatic variations that originated in the highlatitude North Atlantic region, while commensurate changes in Southern Ocean hydrography more directly, and slightly earlier, affected oxygen concentrations in the ETSP. Furthermore, the $\delta^{15} \mathrm{~N}$ records imply ongoing physical communication across the equator in the shallow subsurface continuously over the last $50-70 \mathrm{ka}$.

Citation: Pichevin, L. E., R. S. Ganeshram, S. Francavilla, E. Arellano-Torres, T. F. Pedersen, and L. Beaufort (2010), Interhemispheric leakage of isotopically heavy nitrate in the eastern tropical Pacific during the last glacial period, Paleoceanography, 25, PA1204, doi:10.1029/2009PA001754.

\section{Introduction}

[2] Ice core records from Greenland and Antarctica have revealed that during the last glacial period Earth's climate experienced high-amplitude, abrupt changes at millennial timescales [Chappellaz et al., 1993; Monnin et al., 2001; Petit et al., 1999]. Intriguingly, millennial timescale temperature changes in the high latitudes are asynchronous between both hemispheres [Blunier et al., 1998; Chappellaz et al., 1993; Petit et al., 1999] raising questions about the geographical origin of these climatic perturbations and the nature of the teleconnection between distant areas around the globe [Altabet et al., 2002; Haug et al., 2001; Koutavas et al., 2002; Stott et al., 2002]. In that regard the role of the tropics in initiating or amplifying abrupt climate changes has been extensively discussed [Altabet et al., 2002; Flückiger et al., 2006; Haug et al., 2001; Koutavas et al.,

\footnotetext{
${ }^{1}$ School of Geosciences, University of Edinburgh, Edinburgh, UK.

${ }^{2}$ School of Earth and Ocean Sciences, University of Victoria, Victoria, British Columbia, Canada.

${ }^{3}$ CEREGE, Europôle de l'Arbois, Aix-en-Provence, France.

Copyright 2010 by the American Geophysical Union. 0883-8305/10/2009PA001754\$12.00
}

2002; Stott et al., 2002] but both the timing of changes in the low latitudes and the mechanisms involved remain unclear (Hendy and Pedersen [2006] and, e.g., Kiefer and Kienast [2005]).

[3] Nitrous oxide $\left(\mathrm{N}_{2} \mathrm{O}\right)$ and methane $(\mathrm{CH} 4)$ levels measured in air trapped in ice cores vary in concert with temperature changes in the Northern Hemisphere high latitudes [Flückiger et al., 1999; Spahni et al., 2005], pointing to a link between greenhouse gas emissions and climate change on millennial timescales. Denitrification is a biologically mediated process that transforms nitrate into gaseous $\mathrm{N}_{2}$ and $\mathrm{N}_{2} \mathrm{O}$ in the near absence of oxygen [Cline and Kaplan, 1975]. It is the main sink of fixed $\mathrm{N}$ for the ocean and hence has the potential to act as a climate rheostat through its ability to alter the biological pump of $\mathrm{CO}_{2}$ [Altabet et al., 1995; Ganeshram et al., 1995; McElroy, 1983 ] and modulate greenhouse gas $\left(\mathrm{N}_{2} \mathrm{O}\right.$ and $\left.\mathrm{CO}_{2}\right)$ emissions [Flückiger et al., 1999; Ivanochko et al., 2005; Nevison et al., 2003, 2004; Sowers et al., 2003]. The world's three main oceanic denitrification zones, the eastern tropical North Pacific (ETNP) and eastern tropical South Pacific (ETSP) and the Arabian Sea are located in the tropics, yielding a low-latitude mechanism that could contribute to climate change via modulation of the oceanic $\mathrm{N}$ 
content [Altabet et al., 2002; Ganeshram et al., 2000], as well as production of $\mathrm{N}_{2} \mathrm{O}$ [Sowers et al., 2003; Suntharalingam et al., 2000].

[4] Isotopic discrimination among stable $\mathrm{N}$ isotopes $\left({ }^{14} \mathrm{~N}\right.$ and ${ }^{15} \mathrm{~N}$ ) associated with this process can be used to track denitrification intensity in suboxic areas by determining the $\mathrm{N}$ isotopic composition of either the $\mathrm{N}_{2}$ produced [Brandes et al., 1998; Cline and Kaplan, 1975; Liu and Kaplan, 1989] or the sedimentary organic material [Altabet et al., 1999; Ganeshram et al., 2000] that incorporates isotopically enriched nitrate. Using $\mathrm{N}$ isotopes in sediment cores, numerous studies have established a strong link between millennial-scale denitrification changes in the Arabian Sea, atmospheric $\left[\mathrm{N}_{2} \mathrm{O}\right]$ and temperature variations in Greenland ice cores [Altabet et al., 2002; Ivanochko et al., 2005; Pichevin et al., 2007; Suthhof et al., 2001], fuelling the debate whether denitrification in the oxygen minimum zones (OMZs) plays a key role in triggering or amplifying abrupt climate changes [e.g., Altabet et al., 2002]. However, $\delta^{15} \mathrm{~N}$ records from the ETP have yielded contradictory reconstructions of denitrification history over the last climatic cycle [Hendy and Pedersen, 2006; Kienast et al., 2002; Thunell and Kepple, 2004]. While denitrification changes in the ETSP have been documented to be in phase with temperature variations in Antarctica [De Pol-Holz et al., 2007; Robinson et al., 2007] $\mathrm{N}$ isotope records from the Santa Barbara Basin [Emmer and Thunell, 2000] and North American margin [Hendy et al., 2004] display a clear Greenland timing, implying a strong connection between denitrification and climate in the Northern Hemisphere. It is worth noting however that the $\mathrm{N}$ isotope signature off California is not a direct result of local denitrification intensity as this process does not occur in the water column north of $25^{\circ} \mathrm{N}$. Rather, it reflects the advection of partially denitrified waters northward from the core of the OMZ which lies to the south [Hendy et al., 2004; Kienast et al., 2002]. Therefore, past changes in denitrification in the northern site have been assumed to reflect denitrification changes in the southern ETNP. Surprisingly, recent records from sites located in the core of the OMZ in the ETNP do not show a clear Greenland timing [Hendy and Pedersen, 2006; Thunell and Kepple, 2004], a paradox that has cast doubt on the relationship between denitrification history in the ETP and abrupt climate changes.

[5] Here, we present new high-resolution nitrogen isotope records from two well-dated cores distributed on a northsouth transect across the ETNP that document changes in denitrification over the last $70 \mathrm{ka}$. The Gulf of Tehuantepec site is situated within the core of the subtropical denitrification zone while the Nicaragua site is located at the southern extreme of the OMZ. Denitrification history has never been documented in the Nicaragua Basin in spite of its key location in the ETNP at the boundary between the equatorial divergence zone and the tropical coastal upwelling area. Comparisons between these new results and existing records from both the northeastern and southeastern tropical Pacific [Cannariato and Kennett, 1999; Hendy and Pedersen, 2006; Thunell and Kepple, 2004; De Pol-Holz et al., 2006, 2007] provide new constraints on the timing of denitrification changes in the ETP and on their climatic impact at the millennial timescale.

\section{Material and Methods}

[6] Calypso core MD 02-2524 ( $12^{\circ} 00.55 \mathrm{~N} ; 87^{\circ} 54.83 \mathrm{~W}$; $863 \mathrm{~m}$ water depth) was recovered from the Nicaragua Basin and Calypso core MD 02-2520 (15 $40.14 \mathrm{~N}$; $95^{\circ} 18.00 \mathrm{~W} ; 719 \mathrm{~m}$ water depth) from the Gulf of Tehuantepec during the MONA (Marges Ouest Nord Américaines) cruise of the Marion Dufresne (Internal Marine Global Changes (IMAGES) VIII) in June 2002. The locations of sediment cores used are shown in Figure 1.

\subsection{Construction of the Age Models}

[7] Cores MD 02-2524 and MD 02-2515 are very well dated: the age models are based on 21 and $29 \mathrm{AMS}^{14} \mathrm{C}$ dates, respectively (Figure 2, blue and red squares and Tables 1 and 2). The $\mathrm{AMS}^{14} \mathrm{C}$ dates have been obtained on organic matter samples. Organic matter in both these highly productive, rapidly accumulating sites is of marine origin (as confirmed by the stable $\mathrm{C}$ isotope data shown in Tables 1 and 2). A few mixed planktonic foraminiferabased ${ }^{14} \mathrm{C}$ dates have been paired with organic carbonbased ${ }^{14} \mathrm{C}$ dates (Tables 1 and 2) for core MD 02-2524 and on other Marion Dufresne cores from the ETNP (not shown (E. Arellano-Torres, manuscript in preparation, 2010; R. S. Ganeshram, unpublished data, 2008; L. E. Pichevin, manuscript in preparation, 2010)) and both sample types yield contemporaneous ages within error. Therefore, we are confident that ${ }^{14} \mathrm{C}$ dating on organic carbon is as accurate as radiocarbon dating on mixed planktonic foraminiferal samples. Moreover, the carbonate fraction throughout most of the sediment cores from this region is poorly preserved and scarce, with the exception of the few intervals where dating on foraminifera was possible. Hence, radiocarbon dating on the more abundant organic carbon fraction offers the opportunity to date the record at high resolution and on crucial intervals while achieving greater precision.

[8] The analytical error on the ${ }^{14} \mathrm{C}$ dates ranges from 30 to $<400$ years over the last 25 ka B.P. (Tables 1 and 2) and increases substantially toward the limit of the dating window. Dating error around the last climatic Termination is small ( $<200$ years; see Tables 1 and 2$)$. To calibrate the ${ }^{14} \mathrm{C}$ dates into calendar ages B.P. we applied the MARINE04 model (P. J. Reimer et al., 2004, available at http://calib.qub. ac.uk/calib/) for radiocarbon dates younger than $21 \mathrm{ka}$ and the equation of Bard et al. [2004] for older ages. Existing radiocarbon data show very similar marine reservoir ages today for both sites and little variation across the basin (see http://calib.qub.ac.uk/marine/index.php). Therefore, we applied a total reservoir age correction of $450( \pm 50)$ years for both sites MD-02 2524 and MD-02 2520 in accordance with previous studies [Berger et al., 1966; Ganeshram et al., 1995]. Due to the paucity of foraminifera in core MD-02 2524, an accurate age model beyond the radiocarbon window could not be produced and sedimentation rates established from the ${ }^{14} \mathrm{C}$ dates were extrapolated for the oldest part of the core $(>50 \mathrm{ka})$. 

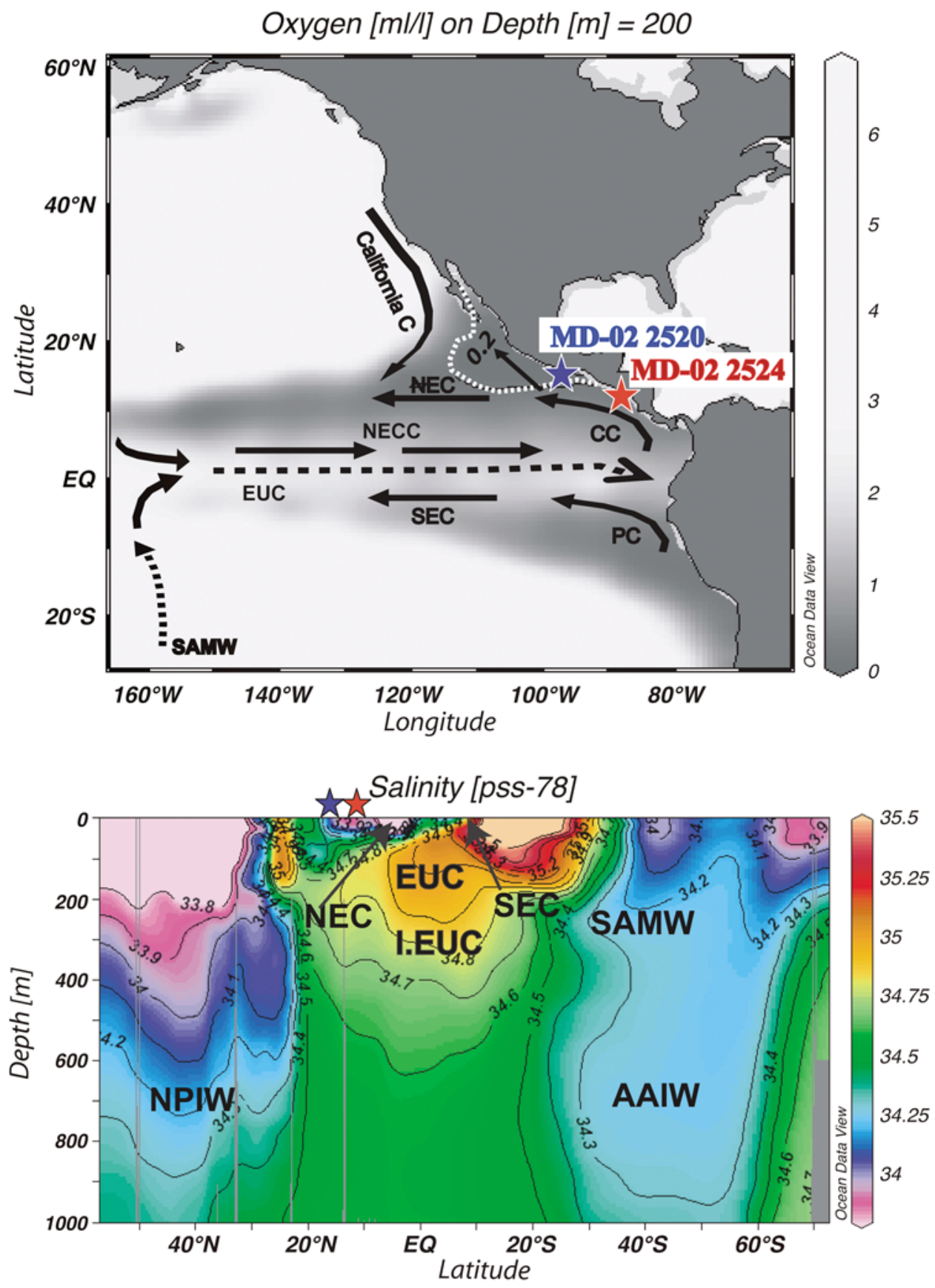

Figure 1. (top) Study area with core sites (stars) and surface and subsurface/intermediate currents (solid and dotted arrows, respectively) showing oxygen concentration at $200 \mathrm{~m}$ water depth. (bottom) Salinity profile in the upper $1000 \mathrm{~m}$ of the water column (WOCE data, plotted with Ocean Data View). CC, Costa Rica Current; EUC, Equatorial Undercurrent; NEC, North Equatorial Current; NECC, North Equatorial Counter Current; SEC, South Equatorial Current; PC, Peru Current; SAMW, sub-Antarctic Mode Water; AAIW, Antarctic Intermediate Water; NPIW, North Pacific Intermediate Water.

\subsection{Isotopic and Elemental Analyses}

[9] Determination of the opal content (\%) was performed by molybdate blue spectrophotometry following Mortlock and Froelich [1989]. Organic carbon (Corg (\%)) and N (\%) contents were determined by using a $\mathrm{CE}$ instrument NA2500 elemental analyzer. A sediment standard (PACS-2) was used for calibration.
[10] The isotopic compositions of sedimentary nitrogen $\left(\delta^{15} \mathrm{~N}\right)$ and carbon $\left(\delta^{13} \mathrm{C}\right)$ were measured by continuous flow-isotope ratio mass spectrometry using a CE instrument NA2500 elemental analyzer directly coupled to a VG Isotech Prism mass spectrometer. About $10-20 \mathrm{mg}$ of freeze-dried, ground bulk sediment is used for elemental and isotopic analyses. Following flash combustion, the $\mathrm{N}_{2}$ 


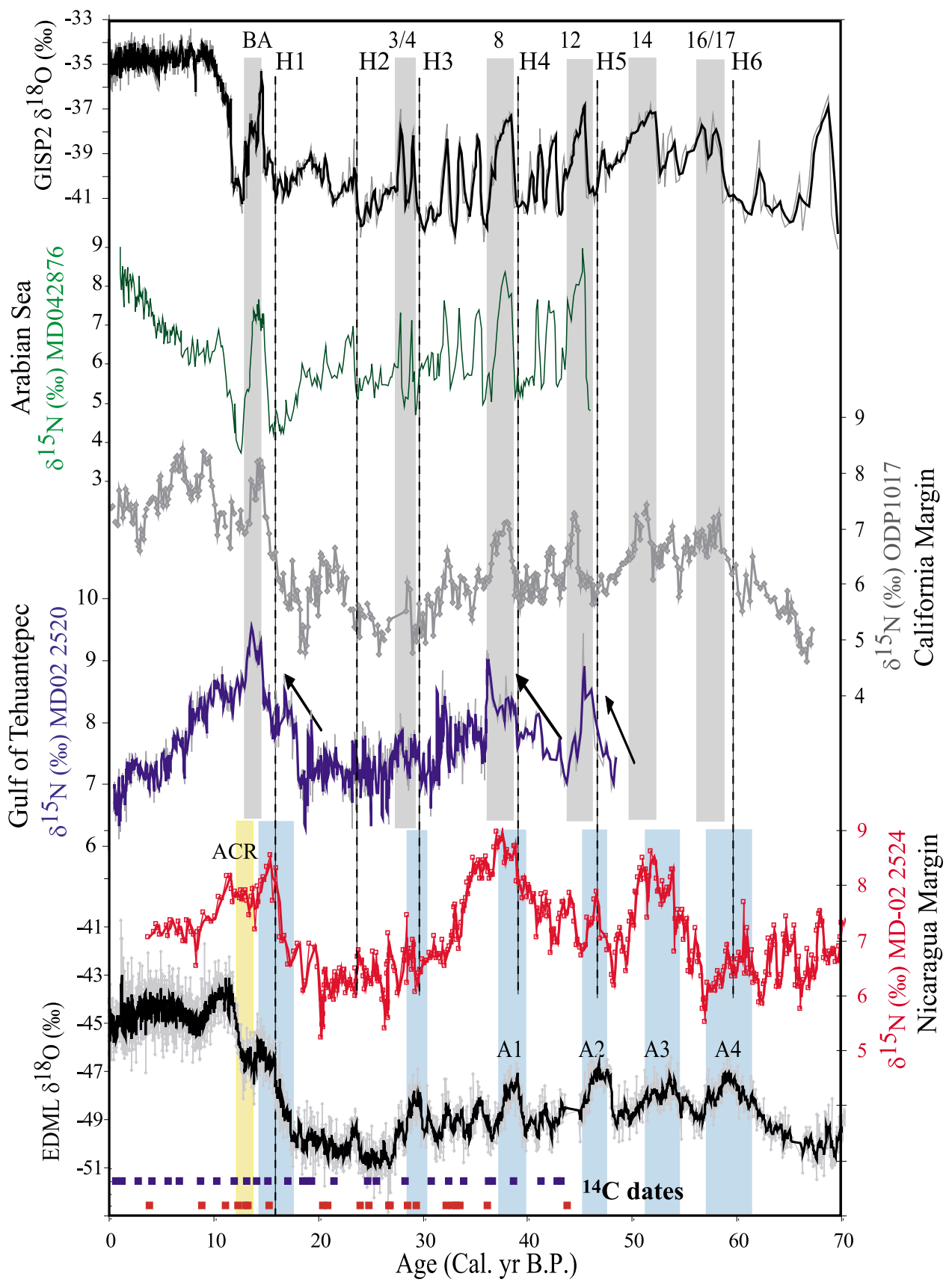

Figure 2. Sedimentary $\delta^{15} \mathrm{~N}$ records from core MD 02-2524 (this study), core MD 02-2520 (this study), core ODP1017 [Hendy et al., 2004] from the ETNP (plotted south to north), and core MD 042876 [Pichevin et al., 2007] from the Arabian Sea compared to $\delta^{18} \mathrm{O}$ records from EPICA Dronning Maud Land (EDML) and GISP2 [EPICA Community Members, 2006; Grootes et al., 1993]. The AMS ${ }^{14} \mathrm{C}$ dates for the two new records are shown at the bottom (color corresponds to record). Shaded areas and dotted lines represent Dansgaard-Oeschger warm events (numbered) and Heinrich events (H1-H6), respectively.

and $\mathrm{CO}_{2}$ gases released from the sample are separated chromatographically. These gases are transferred to the mass spectrometer using helium as a carrier gas. Masses $28,29,30$ and 44, 45, 46 are monitored for $\mathrm{N}$ and $\mathrm{C}$ isotopic measurements, respectively. The ratios of ${ }^{15} \mathrm{~N}^{14} \mathrm{~N}$ and ${ }^{13} \mathrm{C}-{ }^{12} \mathrm{C}$ in the sample are calculated and reported as $\delta^{15} \mathrm{~N}$ relative to atmospheric $\mathrm{N}_{2}$ and $\delta^{13} \mathrm{C}$ relative to Peedee belemnite, respectively. Analytical precision of the instrument based on multiple analyses of a laboratory bulk sediment standard is $+0.2 \%$ ( 1 sigma).

[11] Minor (Mo) and major ( $\mathrm{Al})$ element concentrations were measured by X-ray fluorescence on pressed pellets and glass disks, respectively. The disks and pellets are prepared with $1 \mathrm{~g}$ of dry powdered bulk sediment. All geochemical 
Table 1. $\mathrm{AMS}^{14} \mathrm{C}$ Date-Based Age Model for Core MD $02-2520$ and $\delta^{13} \mathrm{C}$ Data ${ }^{\mathrm{a}}$

\begin{tabular}{|c|c|c|c|c|c|}
\hline Sample Depth (cm) & Material & Calibration Method & Calendar Age (years B.P.) & ${ }^{14} \mathrm{C}$ Age Error $(1 \sigma)$ & $\delta^{13} \mathrm{C}(\%)$ \\
\hline 1 & organic carbon & MARINE04 & 515 & 24 & NA \\
\hline 129 & organic carbon & MARINE04 & 1,048 & 37 & -21.0 \\
\hline 309 & organic carbon & MARINE04 & 2,645 & 36 & -21.3 \\
\hline 404 & organic carbon & MARINE04 & 3,907 & 38 & -20.8 \\
\hline 534 & organic carbon & MARINE04 & 5,442 & 41 & -21.1 \\
\hline 669 & organic carbon & MARINE04 & 6,564 & 43 & -21.3 \\
\hline 844 & organic carbon & MARINE04 & 8,535 & 55 & -21.5 \\
\hline 969 & organic carbon & MARINE04 & 10,155 & 63 & -21.2 \\
\hline 1,073 & organic carbon & MARINE04 & 11,865 & 82 & -21.1 \\
\hline 1,123 & organic carbon & MARINE04 & 13,007 & 86 & -21.4 \\
\hline 1,173 & organic carbon & MARINE04 & 13,954 & 99 & -21.7 \\
\hline 1,222 & organic carbon & MARINE04 & 14,976 & 108 & -21.5 \\
\hline 1,387 & organic carbon & MARINE04 & 16,947 & 133 & -21.1 \\
\hline 1,442 & organic carbon & MARINE04 & 18,310 & 149 & -20.5 \\
\hline 1,492 & organic carbon & MARINE04 & 18,795 & 158 & -20.5 \\
\hline 1,571 & organic carbon & MARINE04 & 19,255 & 172 & -20.7 \\
\hline 1,797 & organic carbon & MARINE04 & 21,394 & 224 & -20.6 \\
\hline 2,112 & organic carbon & MARINE04 & 24,551 & 316 & -20.5 \\
\hline 2,277 & organic carbon & Bard et al. [2004] & 25,422 & 349 & NA \\
\hline 2,475 & organic carbon & Bard et al. [2004] & 28,088 & 480 & -20.6 \\
\hline 2,670 & organic carbon & Bard et al. [2004] & 30,626 & 268 & -21 \\
\hline 2,881 & organic carbon & Bard et al. [2004] & 32,319 & 803 & -21.3 \\
\hline 2,981 & organic carbon & Bard et al. [2004] & 33,765 & 392 & -21 \\
\hline 3,150 & organic carbon & Bard et al. & 36,154 & 527 & -21.2 \\
\hline 3,284 & organic carbon & Bard et al. [2004] & 36,506 & 1,363 & NA \\
\hline 3,329 & organic carbon & Bard et al. [2004] & 38,486 & 712 & -21.5 \\
\hline 3,438 & organic carbon & Bard et al. [2004] & 41,146 & 1,016 & -21 \\
\hline 3,493 & organic carbon & Bard et al. [2004] & 43,078 & 1,326 & -21 \\
\hline 3,573 & organic carbon & Bard et al. [2004] & 45,600 & 3,116 & -21.4 \\
\hline
\end{tabular}

${ }^{\mathrm{a}} \mathrm{NA}$, not available.

analyses were performed at the School of Geosciences, the University of Edinburgh. Results are presented in Figures 2 and 4 .

\section{Oxygen Distribution and Denitrification in the Modern ETNP}

[12] The distribution of $\left[\mathrm{O}_{2}\right]$ in the thermocline waters of the ETNP is shown in Figure 1. Denitrification takes place when $\left[\mathrm{O}_{2}\right]$ falls below $0.2 \mathrm{~mL} / \mathrm{L}$ [Naqvi and Jayakumar,
2000]. At $200 \mathrm{~m}$ water depth in the ETNP the only region that fills this condition year-round is limited to the Mexican Margin between $15^{\circ} \mathrm{N}$ and $25^{\circ} \mathrm{N}$ and the Gulf of California (dashed line in Figure 1). The latitudinal extent and vertical distribution of water column denitrification in the ETNP today has been delimited by Brandes et al. [1998] and Sigman et al. [2003]. Denitrification occurs at significant rates between $15^{\circ} \mathrm{N}$ and $25^{\circ} \mathrm{N}$ at around $200-300 \mathrm{~m}$ water depth [Brandes et al., 1998; Sigman et al., 2003; Thunell and Kepple, 2004]. There, nitrate $\delta^{15} \mathrm{~N}$ exceeds $15 \%$

Table 2. $\mathrm{AMS}^{14} \mathrm{C}$ Date-Based Age Model for Core MD 02-2524 and $\delta^{13} \mathrm{C}$ Data

\begin{tabular}{|c|c|c|c|c|c|}
\hline Sample Depth $(\mathrm{cm})$ & Material & Calibration Method & Calendar Age (years B.P.) & ${ }^{14} \mathrm{C}$ Age Error $(1 \sigma)$ & $\delta^{13} \mathrm{C}(\%)$ \\
\hline 10 & organic carbon & MARINE04 & 3679 & 74 & -20.6 \\
\hline 136 & organic carbon & MARINE04 & 8,681 & 124 & -20.6 \\
\hline 175 & organic carbon & MARINE04 & 11,009 & 103 & -20.7 \\
\hline 175 & foraminifera & MARINE04 & 12,149 & 37 & -0.8 \\
\hline 225 & organic carbon & MARINE04 & 13,134 & 59 & -20.6 \\
\hline 225 & foraminifera & MARINE04 & $12,920.5$ & 41 & -0.8 \\
\hline 280 & organic carbon & MARINE04 & 15,090 & 176 & -20.8 \\
\hline 371 & organic carbon & MARINE04 & 20,255 & 171 & -20.0 \\
\hline 455 & organic carbon & MARINE04 & 20,757 & 285 & -20.5 \\
\hline 601 & organic carbon & MARINE04 & $23,875.5$ & 252 & -20.6 \\
\hline 641 & organic carbon & Bard et al. [2004] & $24,662.2$ & 367 & -20.6 \\
\hline 731 & organic carbon & Bard et al. [2004] & $26,583.2$ & 289 & -20.1 \\
\hline 771 & organic carbon & Bard et al. [2004] & $26,657.9$ & 285 & -20.1 \\
\hline 821 & organic carbon & Bard et al. [2004] & $28,439.6$ & 368 & -20.5 \\
\hline 876 & organic carbon & Bard et al. [2004] & $29,260.2$ & 250 & -20.4 \\
\hline 971 & organic carbon & Bard et al. [2004] & $32,027.5$ & 739 & -20.5 \\
\hline 990 & organic carbon & Bard et al. [2004] & $32,699.6$ & 815 & -20.3 \\
\hline 1,016 & organic carbon & Bard et al. [2004] & $33,032.6$ & 621 & -20.3 \\
\hline 1,041 & organic carbon & Bard et al. [2004] & $33,399.9$ & 539 & -20.2 \\
\hline 1,166 & organic carbon & Bard et al. [2004] & $36,068.7$ & 932 & -20.4 \\
\hline 1,410 & organic carbon & Bard et al. [2004] & $43,596.0$ & 1,426 & -20.4 \\
\hline
\end{tabular}


[Brandes et al., 1998; Sigman et al., 2003; Thunell and Kepple, 2004] and $\left[\mathrm{NO}_{3}\right]$ falls below the concentration expected by the N:P Redfield ratio [Gruber and Sarmiento, 1997], causing a deficit of nitrate $\left(\mathrm{N}^{*}\right)$ relative to phosphate. North of $25^{\circ} \mathrm{N}$, both $\mathrm{NO}_{3}-\delta^{15} \mathrm{~N}$ and $\mathrm{N}^{*}$ decline, recording the cessation of local denitrification and the decreasing influence of denitrified waters as the California Undercurrent moves northward from the core of the OMZ. Nevertheless, Kienast et al. [2002] show that part of the heavy nitrate formed in the $\mathrm{OMZ}$ travels over more than 20 degrees of latitude and influences the $\delta^{15} \mathrm{~N}$ signal of nitrate and organic particles as far north as the west coast of Canada.

[13] The Nicaragua Basin is situated at southern boundary of ETNP denitrification zone (Figure 1). In the subsurface waters (upper $200 \mathrm{~m}$ ) $\left[\mathrm{O}_{2}\right]$ is always $>0.2 \mathrm{~mL} / \mathrm{L}$ (WOA05 data), i.e., more oxygenated than the core of the OMZ between $15^{\circ} \mathrm{N}$ and $25^{\circ} \mathrm{N}$ (Figure 1). Therefore, it is unlikely that denitrification occurs in the Nicaragua Basin at significant rates today.

\section{Reconstruction of Past Denitrification in the ETNP}

\subsection{Gulf of Tehuantepec}

[14] Denitrification changes in the ETNP have been variously attributed to variations in the lateral supply of oxygen (ventilation) and in the oxidant demand resulting from local changes in upwelling and associated productivity, or to a combination of both [Ganeshram et al., 2000; Hendy and Kennett, 2003; Ivanochko and Pedersen, 2004; Kienast et al., 2002; Liu et al., 2005; Stott et al., 2000]. The new $\delta^{15} \mathrm{~N}$ record from Tehuantepec (Figure 2) shows glacial-interglacial and millennial-scale variations, in agreement with known variations in oxygen concentration at intermediate depth in the ETNP [Cannariato and Kennett, 1999]. The new $\delta^{15} \mathrm{~N}$ record compares well with existing records from the Gulf of Tehuantepec over the last $40 \mathrm{ka}$ or so [Hendy and Pedersen, 2006; Thunell and Kepple, 2004] and shows the same progressive increase during the deglaciation and subsequent symmetrical decrease during the Holocene. The Holocene trend has been attributed to a global feedback mechanism between denitrification and $\mathrm{N}$ fixation [Deutsch et al., 2004]. Peaks in the $\delta^{15} \mathrm{~N}$ records from Tehuantepec are generally contemporaneous with warm events in Greenland (Dansgaard-Oeschger $(\mathrm{D} / \mathrm{O})$ interstadials) while episodes of reduced denitrification occur during cold events, i.e., D/O stadials and Heinrich events (Figure 2). However, in comparison to $\delta^{15} \mathrm{~N}$ records from the Arabian Sea (Figure 2), the new Tehuantepec record bears only a partial resemblance to temperature records from Greenland. In particular, the interstadial increases in $\delta^{15} \mathrm{~N}$ from the Tehuantepec site consistently precede the onset of abrupt warming in Greenland by a few hundred to a thousand years. In addition, the peaks in $\delta^{15} \mathrm{~N}$ are relatively symmetrical (progressive increases and decreases) and do not show the typical asymmetry of D/O events (Figure 2, arrows), seen for example in Arabian Sea [Altabet et al., 2002; Pichevin et al., 2007] and northern ETNP records [Hendy et al., 2004].
[15] Existing $\delta^{15} \mathrm{~N}$ records from cores located north of $25^{\circ} \mathrm{N}$, in the Santa Barbara Basin and on the CaliforniaOregon margins [Cannariato and Kennett, 1999; Hendy and Pedersen, 2006; Kienast et al., 2002; Thunell and Kepple, 2004] clearly show a distinctive Greenland timing with sharp increases at the onsets of high-latitude Northern Hemisphere warming periods and progressive decreases during cooling periods (Figure 2). The $\delta^{15} \mathrm{~N}$ variations there correlate with $\mathrm{N}_{2} \mathrm{O}$ records from ice cores, and previous studies have suggested a strong link between denitrification in the ETNP, greenhouse gas emission and past climate change [Flückiger et al., 1999; Sowers et al., 2003; Spahni et al., 2005], an hypothesis that has been recently supported by the modeling results of Schmittner et al. [2007]. However, water column denitrification does not occur north of $25^{\circ} \mathrm{N}$ (Figure 1); the $\delta^{15} \mathrm{~N}$ records from these locations are known to reflect the advection of heavy nitrate from the core of the OMZ, i.e., Gulf of Tehuantepec and Baja California [Hendy et al., 2004; Kienast et al., 2002]. Surprisingly our $\delta^{15} \mathrm{~N}$ record from Tehuantepec does not show a typical Greenland timing, unlike the northern records. These intriguing results raise a number of questions on the history of denitrification changes in the ETNP: Why does the variability in $\delta^{15} \mathrm{~N}$ signal recorded in the California Margin lags $\delta^{15} \mathrm{~N}$ variations in the ETNP, which is thought to be the source area of the signal? What is the source of the nitrate supplied to the California Margin north of $25^{\circ} \mathrm{N}$ ?

\subsection{Nicaragua Basin}

[16] Core MD 02-2524 from the Nicaragua Basin core has provided the first $\delta^{15} \mathrm{~N}$ record south of $15^{\circ} \mathrm{N}$ in the ETNP. The $\mathrm{N}$ isotopic signal from this core varies between 5.5\% and $9 \%$ (Figure 2), comparable to the amplitude of changes measured in the Tehuantepec core. Surprisingly, the $\delta^{15} \mathrm{~N}$ record from this core is radically different from the northern records and shows (1) no synchronicity with temperature changes in Greenland and (2) a timing comparable to Antarctic temperature changes over the last Termination and arguably during the major warming episodes recognized in the Southern Hemisphere high latitudes (A1, A2, A3 and A4 in Figure 2). During the Last Termination, for instance, the $\mathrm{N}$ isotopic signal from the Nicaragua core starts to increase at $20 \mathrm{ka} \mathrm{B.P.} \mathrm{and} \mathrm{peaks} \mathrm{at} \mathrm{around} 15 \mathrm{ka}$, a thousand years prior to the Bølling-Allerød (B/A). Subsequently, a marked decrease is observed at 13 ka B.P., concurrent with the Antarctic Cold reversal (ACR) observed in Antarctic $\delta^{18} \mathrm{O}$ records.

[17] We use two different statistical methods to constrain the phase relationship between high-latitude temperatures and $\delta^{15} \mathrm{~N}$ changes in the Nicaragua Basin and the Gulf of Tehuantepec (Figure 3). The best fit results (calculated as the smallest arithmetic difference between two records) and the time lag correlations both show that the Tehuantepec $\delta^{15} \mathrm{~N}$ record lags the Nicaragua $\delta^{15} \mathrm{~N}$ record by 1300 years, comparable to the phase lag between Greenland and Antarctic temperatures $\left(\delta^{18} \mathrm{O}\right)$, as shown in Figure 3 . Such a large and consistent lag cannot be explained by the uncertainty attached to the ${ }^{14} \mathrm{C}$ dates nor the choice of the reservoir ages (section 2.1). This timing difference further suggests that, in spite of early increases in $\delta^{15} \mathrm{~N}$ during 

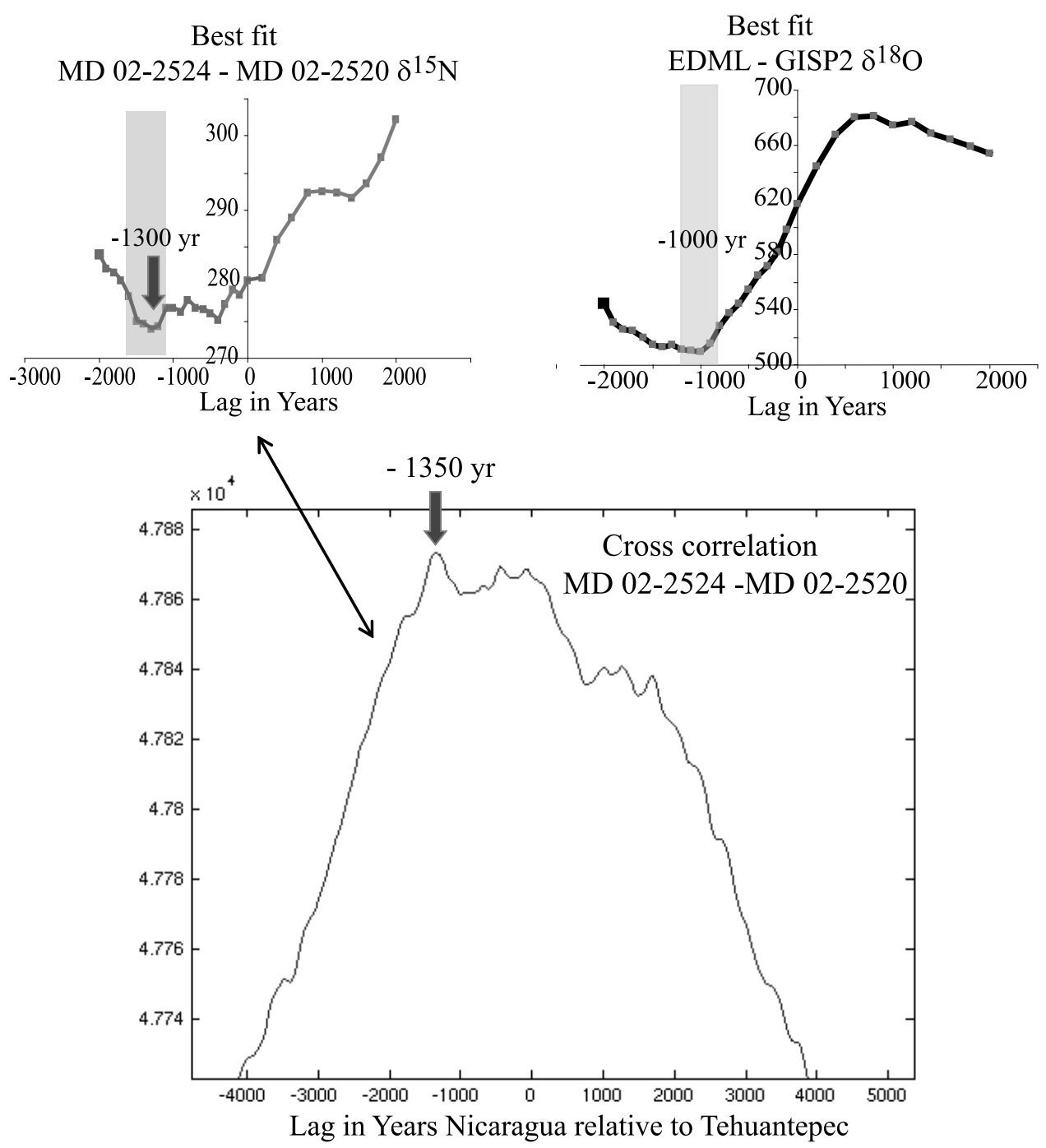

Figure 3. (top) Independent best fit estimates calculated as the time lag between both cores that gives the minimum integrated difference (no units) between pairs of $\delta^{15} \mathrm{~N}$ or $\delta^{18} \mathrm{O}$ (EDML versus GISP2) records. This method yields a very similar result (1300 years) to the cross correlation between MD 02-2520 and MD 02-2524. (bottom) Cross correlation between the $\delta^{15} \mathrm{~N}$ records from MD 02-2520 and MD 02-2524. Briefly, Fourier transforms (FT) of each evenly sampled extrapolated records were calculated, and the complex conjugate of the MD 02-2524 result was multiplied by the function derived from MD 02-2520, i.e., FT(MD 02-2524) $\times$ FT(MD 02-2520). The result was inverse Fourier transformed back to the time domain. The maximum value (no units) occurs for the time lag that gives the best cross correlation (here 1350 years).

Heinrich events (H1, H4 and H5; Figure 2) denitrification changes in the Gulf of Tehuantepec are largely synchronous with temperature changes observed in Greenland whereas the Nicaragua record is in phase with Antarctic climate. Thus, the timing of $\delta^{15} \mathrm{~N}$ variations in the Nicaragua Basin differs from the rest of the ETNP, suggesting that the histories and causes of denitrification changes in the ETNP could have multiple origins. There are two potential explanations for the observed contrasts: (1) denitrification history in the Nicaragua Basin is local and controlled by specific mechanisms related to climate changes in the Southern Hemisphere high latitudes and (2) the $\delta^{15} \mathrm{~N}$ signal in the Nicaragua Basin does not reflect local denitrification and is related to episodic advection of heavy nitrate from elsewhere. These hypotheses are explored in section 5.

\section{Origin of the $\delta^{15} \mathrm{~N}$ Signal off Nicaragua}

5.1. Past Changes in Productivity, Oxygen, and $\delta^{15} \mathrm{~N}$

[18] Oxygen profiles point to the absence of local denitrification in the Nicaragua basin today: oxygen concentration at 200-300 m water depth is above the $0.2 \mathrm{~mL} / \mathrm{L}$ limit required for denitrification to take place (section 3 and Figure 1). This suggests that the heavy $\delta^{15} \mathrm{~N}$ signal observed during the late Holocene in core MD 02-2524 and today south of $15^{\circ} \mathrm{N}$ [Altabet, 2001; Farrell et al., 1995] cannot 


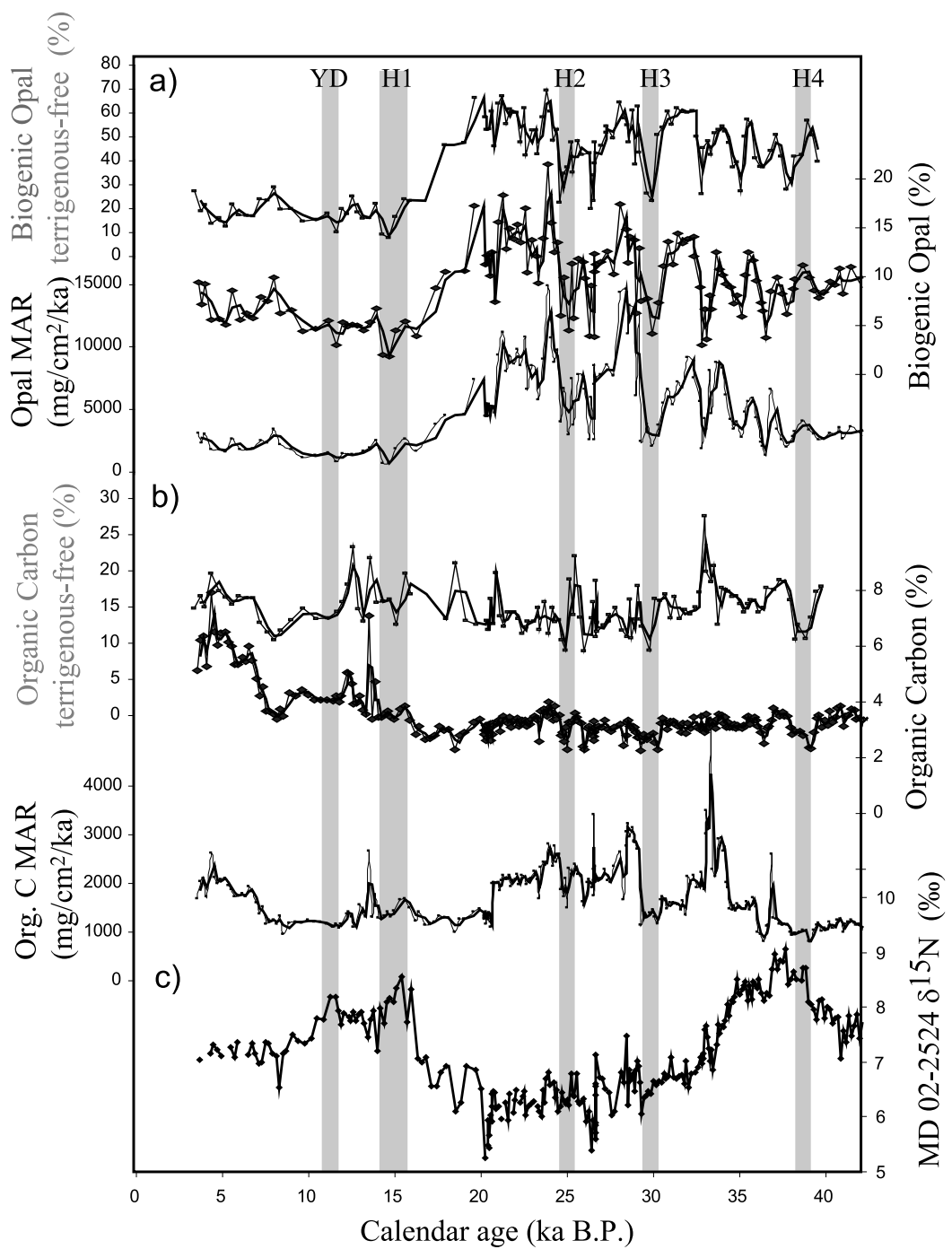

Figure 4. (a) Opal mass accumulation rates (MAR), wt $\%$ on a terrigenous-free basis, and wt $\%$ and (b) organic carbon MAR, wt \% on a terrigenous-free basis, and wt \% compared to (c) $\delta^{15} \mathrm{~N}(\% \mathrm{o})$ in core MD 02-2524.

result from local denitrification. Therefore, we propose that Holocene $\delta^{15} \mathrm{~N}$ values greater than the oceanic $\delta^{15} \mathrm{~N}_{\mathrm{NO} 3}$ average (5\%) [Sigman et al., 1997] represent advection of "heavy" nitrate from the northern or the southern denitrifying zone. The situation could have been different during the last glacial transition, however. Could denitrification have occurred locally at that time?

[19] In both the ETNP [Hendy et al., 2004] and the Arabian Sea [i.e., Altabet et al., 2002; Ivanochko et al., 2005] sedimentary Corg and/or opal contents have been shown to correlate with denitrification changes $\left(\delta^{15} \mathrm{~N}\right)$ at millennial timescales implying that upwelling-induced productivity changes modulate denitrification rates. The temporal relationship between $\delta^{15} \mathrm{~N}$ and local productivity using Corg and opal contents in the Nicaragua core over the last $42 \mathrm{ka}$ is evaluated in Figure 4. At this site, between $55 \%$ and $85 \%$ of the sediment is constituted by terrigenous material. Therefore, it is important to correct $\mathrm{C}_{\text {org }}$ and opal concentrations for the effect of dilution by terrigenous input before using these parameters for paleoproductivity reconstruction; accordingly, the $\mathrm{C}_{\text {org }}$ and opal records are also presented on a terrigenous-free basis in Figure 4. Organic matter $\delta^{13} \mathrm{C}$ measured down core varies between $-19 \%$ and $-21 \%$ (not shown), indicating that the organic matter is of strictly marine origin [Calvert et al., 2001]. In contrast with the northern part of the ETNP [Hendy et al., 2004], $\mathrm{C}_{\mathrm{org}}$ concentrations (on a terrigenous-free basis) show no apparent correlation with the $\delta^{15} \mathrm{~N}$ signal in core MD 02-2524. In addition, opal percent (terrigenous-free basis) content and $\delta^{15} \mathrm{~N}$ show an inverse relationship: high siliceous production (glacial MIS 2) is indicated when the $\delta^{15} \mathrm{~N}$ is low, and low siliceous production (Holocene and Heinrich events) when $\delta^{15} \mathrm{~N}$ values are generally high. Similarly, records of opal and organic carbon mass accumulation rates (MAR) (Figure 4) calculated for the Nicaragua core are not correlated with the $\delta^{15} \mathrm{~N}$ signal. Collectively, these results indi- 


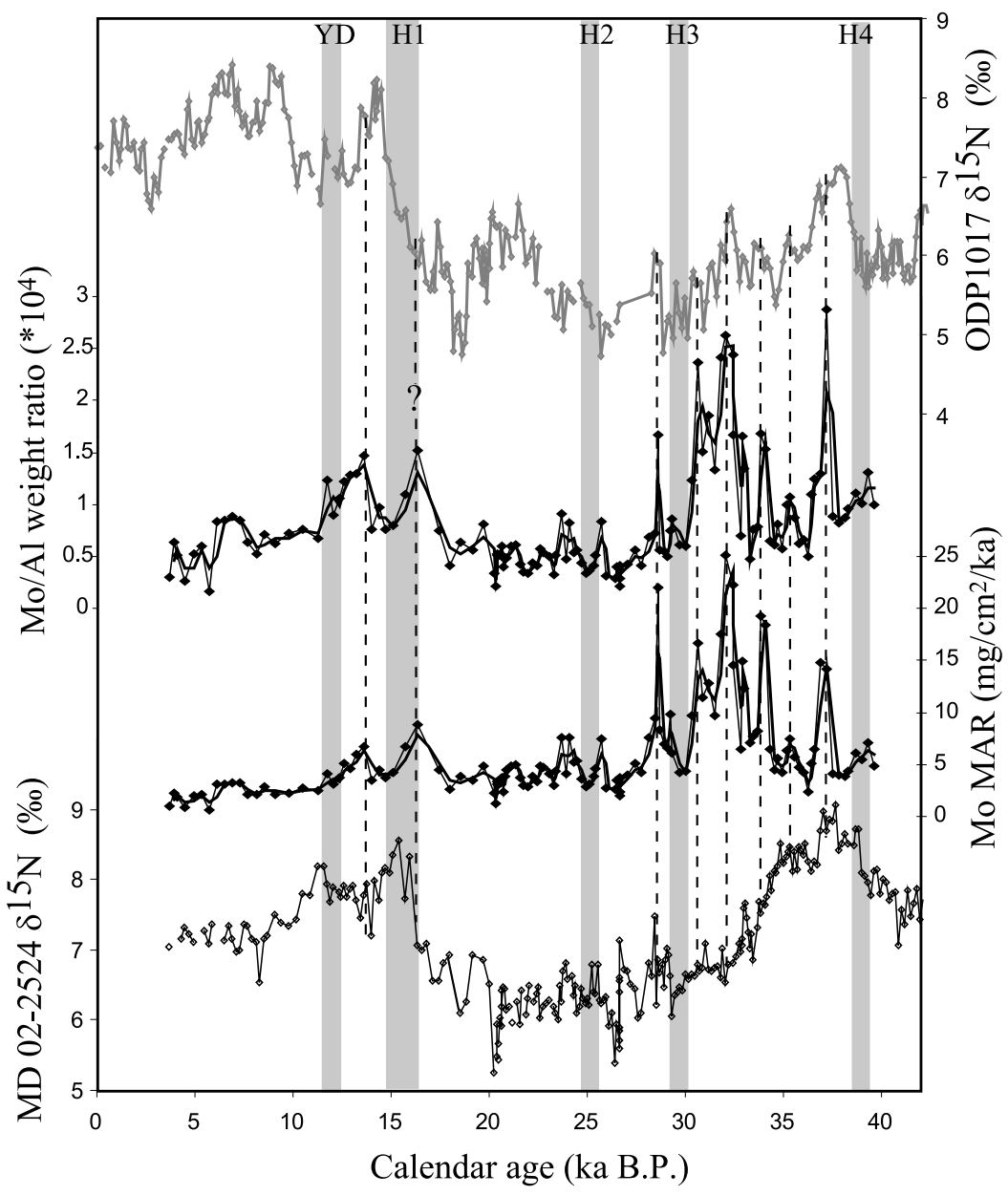

Figure 5. Molybdenum $M A R$ and excess calculated as Mo content normalized to aluminum concentration in core MD 02-2524 compared to the $\delta^{15} \mathrm{~N}(\%)$ records from core MD 02-2524 (bottom curve) and ODP1017 [Hendy et al., 2004] over the last 40 ka.

cate that productivity and the associated variations in oxidant demand in the underlying waters cannot explain the $\delta^{15} \mathrm{~N}$ changes in the Nicaragua Basin.

[20] In rapidly accumulating margin sediments like the Nicaragua Basin $(40 \mathrm{~cm} / \mathrm{ka})$, where oxidation depth is likely to be small compared to burial rate, [Mo] excess (i.e., Mo in excess of lithogenic material calculated as $\mathrm{Mo} / \mathrm{Al}$ ) can be considered a reasonably robust tracer of reducing conditions [Crusius et al., 1999]. The Mo record shown in Figure 5 illustrates changes in bottom water or uppermost pore water oxygen concentration at around $800 \mathrm{~m}$ water depth at the core site. Figure 5 reveals that episodes of increased Mo reduction (low oxygen) do not occur in phase with increased productivity or $\delta^{15} \mathrm{~N}$ in the Nicaragua Basin but are contemporaneous, within dating errors, with $\delta^{15} \mathrm{~N}$ increases recorded further north on the California Margin during MIS 3 and the $\mathrm{B} / \mathrm{A}$ (with the exception of 2 data points at around $16 \mathrm{ka})$. This suggests that oxygen concentrations at the sediment-water interface in the Nicaragua Basin are not controlled by oxidant demand created locally by settling organic matter, but rather are modulated by preformed intermediate water oxygenation. This implies that oxygen concentration at $800 \mathrm{~m}$ water depth in the Nicaragua basin and denitrification in the northern ETNP vary in concert and hence are both controlled by the contractions and expansions of the $\mathrm{OMZ}$ on millennial timescales.

[21] One can argue that the Mo/Al and Mo MAR records from $800 \mathrm{~m}$ water depth presented here do not capture changes in $\mathrm{O}_{2}$ concentration at shallower depths $(100-300 \mathrm{~m}$ water depths) in the Nicaragua Basin. Such $\left[\mathrm{O}_{2}\right]$ variations in the subsurface ocean might have triggered and modulated local denitrification with a Southern Hemisphere timing. However, this hypothesis is weakened by two caveats: First, it is expected that in highly productive regions, oxidant demand related to organic matter degradation would be an overriding factor in controlling $\mathrm{O}_{2}$ concentrations and potential denitrification at shallow water depth. Second, subsurface waters coming from the equatorial region to the Costa Rica Dome and Nicaragua Basin are well oxygenated due to permanent ventilation via the equatorial subsurface current system [Fiedler, 2002; Fiedler and Talley, 2006; Kessler, 2006]. Although variations in oxygen 


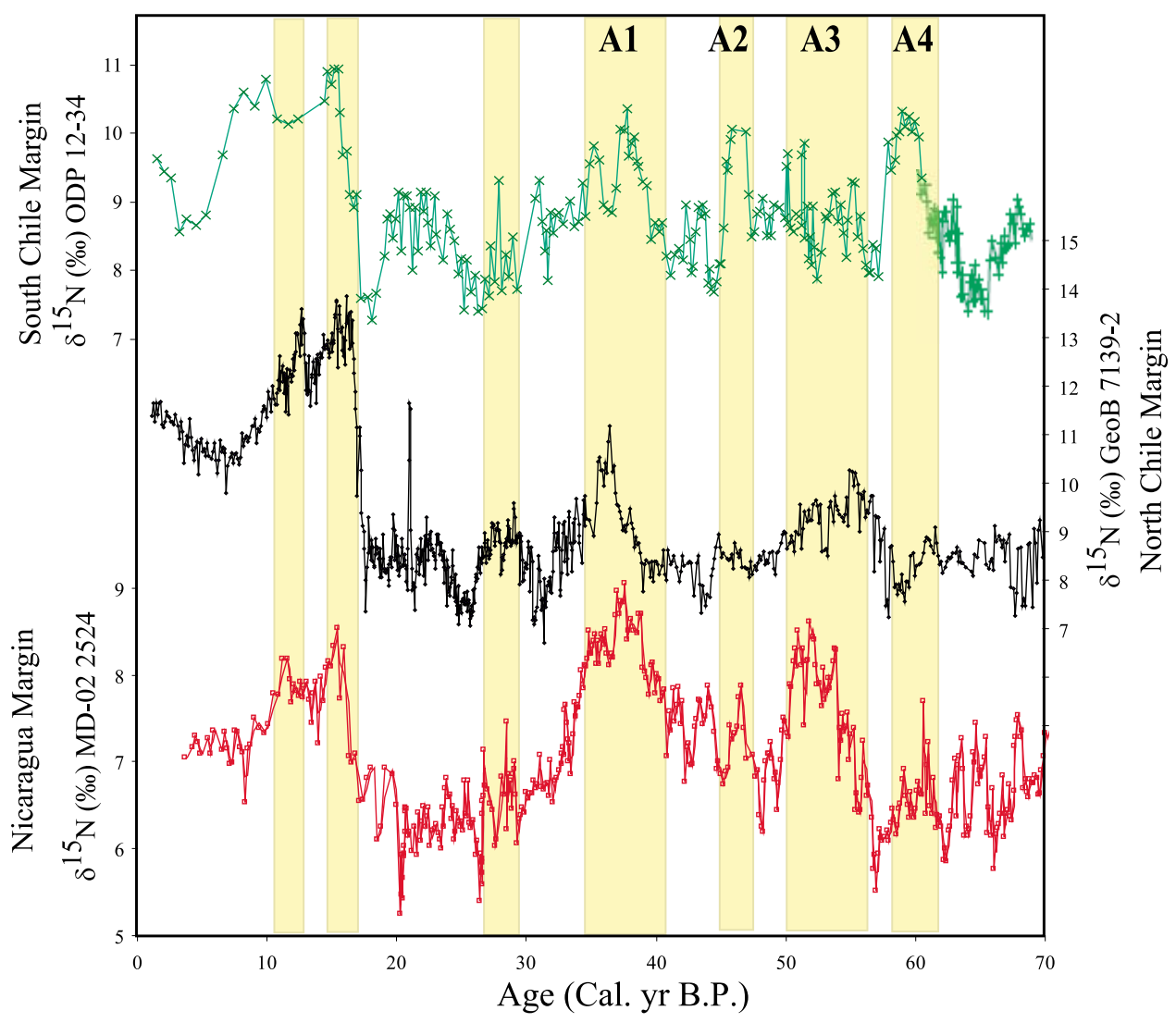

Figure 6. Comparison between denitrification records from core GeoB7139-2 (North Chile Margin) [De Pol-Holz et al., 2007], core ODP12-34 [Robinson et al., 2007] (South Chile Margin), and core MD 02-2524 (Nicaragua Basin). Shaded areas represent periods of warming in Antarctica (A1-A4).

supply to the low-latitude Pacific during the last deglaciation $(18-11 \mathrm{ka})$ cannot be completely ruled out given the probable large-scale reorganization in ocean circulation at that time, we find no evidence for such change in the records.

[22] Given the absence of correlation between the $\delta^{15} \mathrm{~N}$ record from core MD 02-2524 and the productivity and oxygenation data, we find no evidence that denitrification occurred at $12^{\circ} \mathrm{N}$. Therefore, the $\delta^{15} \mathrm{~N}$ record from the Nicaragua Basin does not reflect past variations in local denitrification. Instead we propose that it records the advection of (heavy) nitrate from the Southern Hemisphere OMZ.

\subsection{Heavy Nitrate Leakage From the Peru-Chile Margin}

[23] Denitrification changes on the Peru-Chile Margin [De Pol-Holz et al., 2007; Higginson and Altabet, 2004; Robinson et al., 2007] and the $\delta^{15} \mathrm{~N}$ signal off Nicaragua over the last $70 \mathrm{ka}$ are in good agreement; all three records display an enrichment in the heavy $\mathrm{N}$ isotope during warming episodes in Antarctica (yellow stripes in Figure 6). Some mismatches at around 35 ka between core GeoB7139-2 and our record may be related to dating uncertainties close to the limit of the ${ }^{14} \mathrm{C}$ window. This comparison suggests that the $\delta^{15} \mathrm{~N}$ record from core MD 02-2524 results from the advection of heavy nitrate from the denitrification zones of the ETSP (Figures 6 and 7). During Heinrich events denitrification is reduced in the ETNP but is at its maximum in the ETSP, matching Antarctic warming phases [De PolHolz et al., 2006, 2007; Higginson and Altabet, 2004; Robinson et al., 2007] (Figure 6). Therefore we postulate that the contemporaneous $\delta^{15} \mathrm{~N}$ enrichments recorded off Nicaragua are the result of northward, cross-equatorial advection of heavy nitrate generated from intense denitrification in the Peru-Chile Margin. The complex current and water mass structures and interactions in the eastern equatorial Pacific have been only partially described [Fiedler and Talley, 2006; Kessler, 2006], and water mass exchanges across the equator are still incompletely known in this region [Kessler, 2006]. However, extant hydrographic data can be used to define a potential route by which denitrified waters could be advected across the equator.

[24] The distribution of $\mathrm{N}^{*}$ at $50 \mathrm{~m}$ water depth and cross sections of salinity and $\mathrm{N}^{*}$ in the upper $500 \mathrm{~m}$ water depth are shown in Figure 7. $\mathrm{N}^{*}$ represents the deficit of nitrate, relative to the predicted N:P Redfield ratio, via denitrification [Gruber and Sarmiento, 1997]. It is not a conservative tracer as it is affected, for instance, by $\mathrm{N}$ fixation or the relative regeneration of organic $\mathrm{N}$ and $\mathrm{P}$ as the water travels 

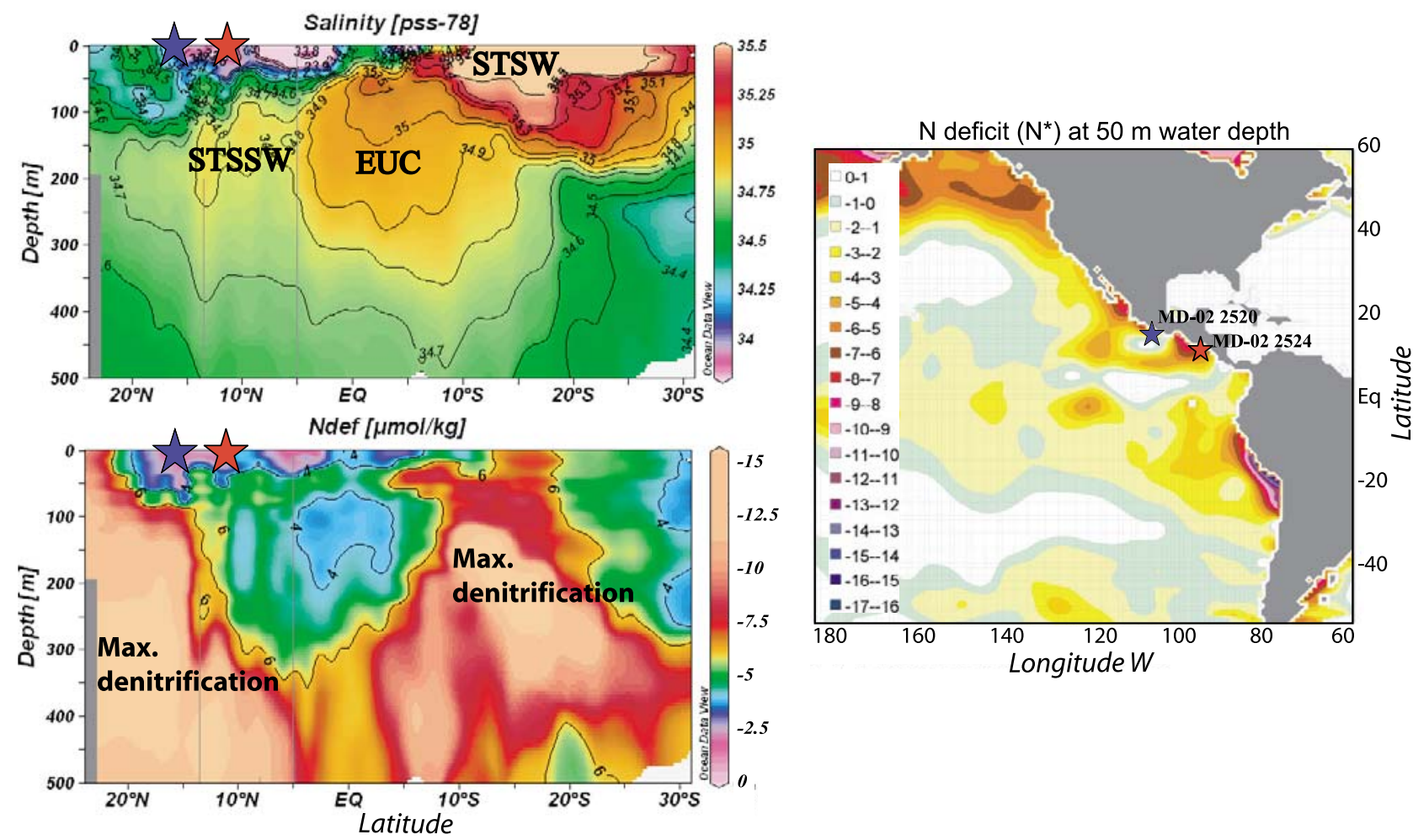

Figure 7. WOCE data of $\mathrm{N}$ deficit calculated according to Gruber and Sarmiento [1997] (right) at $50 \mathrm{~m}$ and (bottom left) in the upper $500 \mathrm{~m}$ in a cross section of the ETP and (top left) salinity (pps78) in the upper $500 \mathrm{~m}$ in a cross section of the ETP. The cross section goes along the American coast line. STSW, Subtropical Surface Water; EUC, Equatorial Undercurrent; STSSW, Subtropical Subsurface Water. Red and blue stars represent core MD 02-2524 and core MD 02-2520, respectively.

away from its source. However, $\mathrm{N}^{*}$ has the potential to indicate whether a parcel of water has been denitrified along the way. Maximum denitrification in the ETNP occurs between 200 and $350 \mathrm{~m}$ water depth [Brandes et al., 1998; Sigman et al., 2003] whereas it occurs at 100-200 m water depth in the ETSP. At $200 \mathrm{~m}$ depth, a severe nitrate deficit is observed in both the southern and northern OMZs (more negative $\mathrm{N}^{*}$ ) but this feature is not present in the Nicaragua basin, reflecting the absence of local denitrification at that depth in this area as suggested earlier. This implies that the leakage of heavy nitrate from the ETSP might occur above this depth, in the 50-200 m subsurface interval. The cross sections in Figure 7 suggest the passage of denitrified water (as a tongue of negative $\mathrm{N}^{*}$ ) from the southern tropical region to the equatorial region and arguably to the Northern Hemisphere at around 50-100 m water depth. A pool of denitrified water at around $50 \mathrm{~m}$ depth stretches from the Peruvian coast into the EUC and arguably the Nicaragua basin.

[25] We attribute this northward propagation of denitrified water to the subduction of high-salinity Subtropical Surface Water (STSW) from above the core of the southern OMZ at around $25^{\circ} \mathrm{S}-10^{\circ} \mathrm{S}$ (Figure 7). This well-oxygenated, superficial water mass contains a large pool of nitrate regenerated from the degradation of organic matter produced in the
Peru-Chile upwelling region [Toggweiler and Carson, 1995]. As part of the subtropical mode water, the STSW subsequently reaches into the EUC and into the North Pacific Subtropical Subsurface Water (STSSW), shown in Figure 7 as a broad salinity maximum between 100 and $200 \mathrm{~m}$ water depth. The STSSW, a derivation of the EUC, fuels the Costa Rica Dome and Nicaragua Basin [Fiedler and Talley, 2006; Kessler, 2006; Wyrtki, 1966].

[26] In their model, Toggweiler and Carson [1995] illustrate the role of the equatorial Pacific current system in distributing nutrients to the ETSP and ETNP. In particular, they show that the pools of nitrate regenerated in the subsurface in the equatorial and Peru-Chile regions merge in the eastern part of the basin, enabling mixing of the partly denitrified nitrate from the southern $\mathrm{OMZ}$ with the equatorial water, and subsequent redistribution via the equatorial subsurface circulation. Although this pathway inevitably results in the dilution of the heavy nitrate pool, we expect that a substantial proportion reaches the Costa Rica Dome and Nicaragua Basin.

[27] Although modern observations can only be used as a rough guide for the past, they do demonstrate the feasibility for cross equatorial exchange of denitrified heavy nitrate. Therefore, we propose that the advection of denitrified waters from the South Pacific could have significantly 

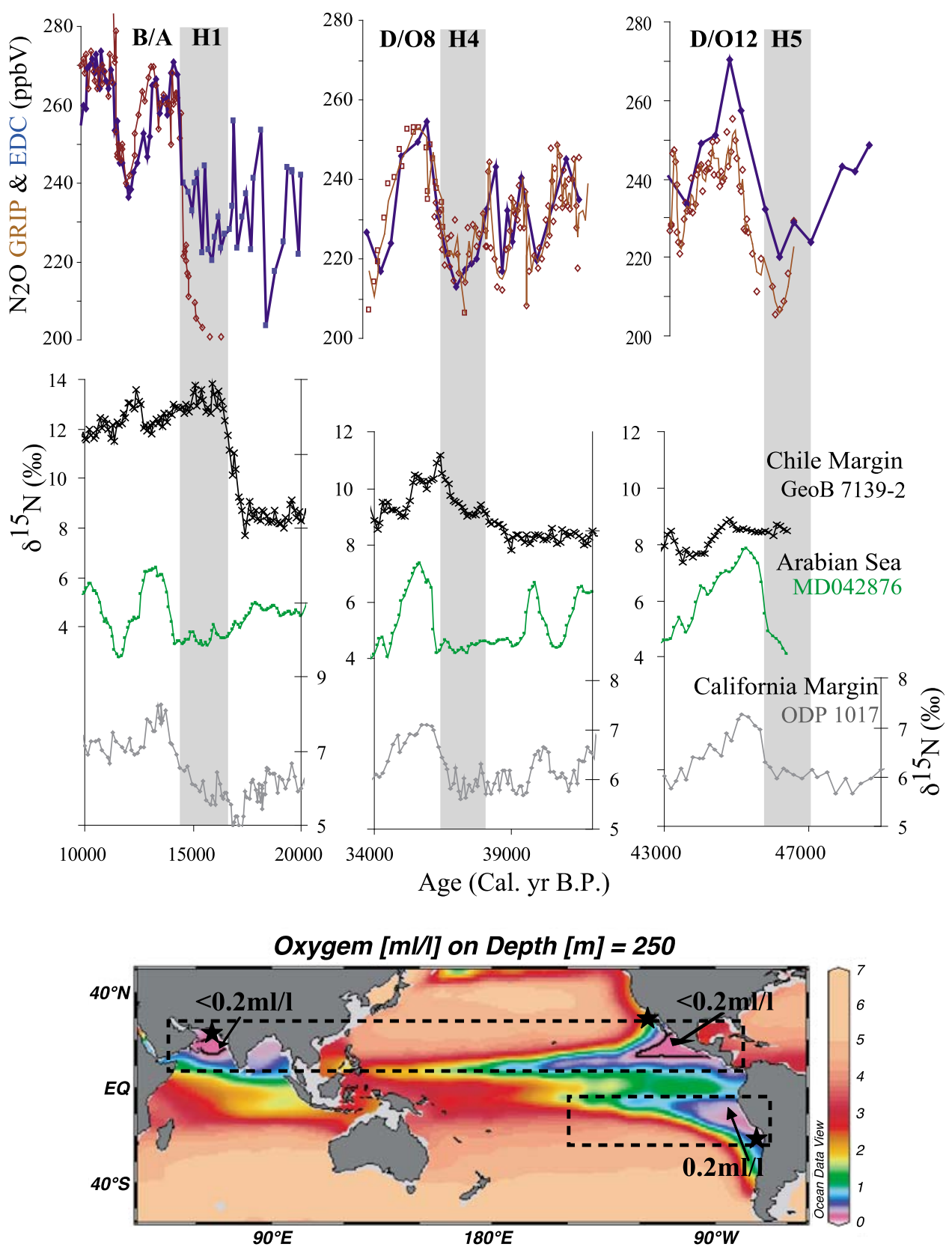

Figure 8. (top) The $\delta^{15} \mathrm{~N}$ records from core GeoB7139-2 (black) [De Pol-Holz et al., 2007] from the Chile Margin representing denitrification changes in the ETSP, core MD 042876 (green) [Pichevin et al., 2007] from the Arabian Sea, and core ODP1017 [Hendy et al., 2004] (gray) from the California margin representing denitrification changes in the Northern Hemisphere OMZs are compared to $\mathrm{N}_{2} \mathrm{O}$ concentrations in EPICA Dome C and GRIP ice cores [Flückiger et al., 1999; Spahni et al., 2005] during selected millennial timescale events: Heinrich 1-Bølling-Allerød (H1/B-A), Heinrich 4-Dansgaard-Oeschger 8 (H4-D/O8), and Heinrich 5-Dansgaard-Oeschger 12 (H5-D/O12). (bottom) Oxygen concentration at $250 \mathrm{~m}$ water depth (WOCE data) showing the distribution of the world's OMZs.

altered the $\mathrm{N}$ isotopic composition of nitrate supplied to the Nicaragua Basin (and potentially Tehuantepec), especially during past periods of intense denitrification in the PeruChile OMZ and decreased denitrification in the ETNP. In particular, we speculate that the southward shifts of the ITCZ documented during cold periods such as Heinrich events and the associated changes in the surface water current and upwelling systems around the equator [Ivanochko et al., 2005; Kienast et al., 2006; Koutavas and Lynch-Stieglitz, 2003, 2004] could have enhanced the passage of subsurface water from the south to the Nicaragua 
Basin at times of intense denitrification in the Peru-Chile OMZ.

\section{Implications for the Timing of Denitrification Changes in the ETNP}

[28] To date, millennial-scale denitrification history in the ETNP and its connection with the northern or southern high-latitude climate has remained unclear [Hendy and Pedersen, 2006; Hendy et al., 2004; Thunell and Kepple, 2004]. Records located north of the ETNP denitrification zones display $\delta^{15} \mathrm{~N}$ changes that are apparently synchronous with Greenland temperature changes over the last glacial cycle [Hendy et al., 2004; Kienast et al., 2002; Thunell and Kepple, 2004]. Such comparisons were interpreted as indirect evidence that denitrification in the ETNP (between $15^{\circ} \mathrm{N}$ and $25^{\circ} \mathrm{N}$ ) varies in concert with Northern Hemisphere high latitudes climate. However, a recent $\delta^{15} \mathrm{~N}$ record from the Gulf of Tehuantepec, within the core of the OMZ, has cast doubt on this supposition [Hendy and Pedersen, 2006], suggesting that hydrographic variability in the Antarctic region modulated denitrification in the southern part of the ETNP. This inference was based on the observation that the deglacial $\mathrm{N}$ isotopic signal in Gulf of Tehuantepec sediments starts to increase at $17-18$ ka B.P., in phase with the deglacial temperature increase in Antarctica. Reconciliation of the contrast between the Tehuantepec and more northerly records can be achieved if the Tehuantepec record represents a combination of both local denitrification changes and an advected signal from the south.

[29] Our new Tehuantepec record exhibits both Northern Hemisphere and Southern Hemisphere climatic influences. Early increases in $\delta^{15} \mathrm{~N}$ occur mainly during $\mathrm{H} 1, \mathrm{H} 4$ and $\mathrm{H} 5$ (Figure 2, arrows), but maximum $\delta^{15} \mathrm{~N}$ values occur during Greenland (Dansgaard-Oeschger) warm spells and not during Antarctic warming episodes. This implies that denitrification in the ETNP is maximum during interstadials (when temperatures were highest in Greenland). In the Nicaragua Basin, south of the denitrification zone, the early and gradual increases in $\delta^{15} \mathrm{~N}$ during Heinrich events almost certainly result from the advection of heavy nitrate from the Southern Hemisphere OMZ (section 5) that penetrates further north into the ETNP denitrification zone and influences the $\delta^{15} \mathrm{~N}$ signal in the Gulf of Tehuantepec (and probably beyond). Thus, we propose that the sedimentary $\delta^{15} \mathrm{~N}$ records from this locale reflect the interplay of two components: (1) local/regional denitrification changes that peak during Greenland warm spells and (2) the advection of heavy nitrate from the southern OMZ that causes the gradual and early increase in $\delta^{15} \mathrm{~N}$ during Heinrich events. A broader implication is that local denitrification in the ETNP varies abruptly with a Northern Hemisphere climate pacing in concert with denitrification in the Arabian Sea, and abrupt changes in Greenland temperatures and atmospheric $\mathrm{N}_{2} \mathrm{O}$ [Flückiger et al., 1999, 2006; Sowers et al., 2003].

[30] It is well documented that denitrification in the PeruChile margin varies with an Antarctic timing [De Pol-Holz et al., 2006; Robinson et al., 2007]. This should have influenced the timing of past oceanic $\mathrm{N}_{2} \mathrm{O}$ emissions at millennial timescales, but to what extent relative to the integrated global efflux? Figure 8 qualitatively addresses this question. During Heinrich events, the early increases in denitrification in the Peru-Chile area are compensated by decreases in denitrification in the other OMZ (Figure 8). During $\mathrm{D} / \mathrm{O}$ warm events however denitrification in the Peru-Chile area plateaus whereas it sharply increases in the Northern Hemisphere tropics (Figure 8). The very close correspondence between variations in the concentration of ice core $\mathrm{N}_{2} \mathrm{O}$ and the Arabian Sea and California Margin denitrification records strongly suggests that $\mathrm{N}_{2} \mathrm{O}$ production in the ocean has been dominated by Northern Hemisphere OMZ denitrification for at least the last $50 \mathrm{ka}$.

\section{Conclusions}

[31] Sedimentary $\delta^{15} \mathrm{~N}$ variability in a core from the Nicaragua Basin collected just south of the modern ETNP denitrification zone exhibits an Antarctic timing similar to denitrification changes off Peru-Chile. We attribute this to the leakage of isotopically heavy nitrate from the South American OMZ to the Nicaragua Basin. This imprints a Southern Hemisphere signal on a Northern Hemisphere $\delta^{15} \mathrm{~N}$ record, and reflects an earlier start to denitrification in the ETSP that corresponds with warming in Antarctica during the initial stages of Heinrich events.

[32] It follows that the $\delta^{15} \mathrm{~N}$ signal from Tehuantepec and the ETNP in general cannot be interpreted directly as a tracer of local denitrification; rather it represents an amalgam of Southern Hemisphere and Northern Hemisphere climatic influences. The corollary to this finding is that local denitrification in the ETNP varied abruptly in synchronicity with Greenland temperature changes, further connecting denitrification changes in the Northern Hemisphere tropics and climate in the northern high latitudes.

[33] Acknowledgments. This research has been funded by a Marie Curie Intra-European fellowship to L.E.P. and support from the Natural Environment Research Council (NERC) to R.S.G. and L.E.P. The cores were retrieved by the R/V Marion Dufresne through the IMAGES IV program and supported by European Science Foundation Grant to R.S.G. We thank the NERC Radiocarbon laboratory and Steve Moreton for radiocarbon analysis. The authors are grateful for the coring wizardry of Yvon Balut and his team on board the Marion Dufresne and thank I. Hendy, G. Leduc, C. Blanchet, and A. Chan for thoughtful discussions. We are very grateful to $\mathrm{C}$. Chilcott for his help with the $\mathrm{C} / \mathrm{N}$ analyses. T. Pool performed the cross correlations between the $\delta^{15} \mathrm{~N}$ records, for which we are very thankful.

\section{References}

Altabet, M. A. (2001), Nitrogen isotopic evidence for micronutrient control of fractional $\mathrm{NO}_{3}$ utilization in the equatorial Pacific, Limnol. Oceanogr., 46, 368-380.
Altabet, M. A., R. Francois, D. W. Murray, and W. L. Prell (1995), Climate-related variations in denitrification in the Arabian Sea from sedi- ment ${ }^{15} \mathrm{~N} /{ }^{14} \mathrm{~N}$ ratios, Nature, 373, 506-509, doi: $10.1038 / 373506 \mathrm{a} 0$.

Altabet, M. A., D. W. Murray, and W. L. Prell (1999), Climatically linked oscillations in Ara- 
bian Sea denitrification over the past 1 m.y.: Implications for the marine $\mathrm{N}$ cycle, Paleoceanography, 14, 732-743, doi:10.1029/ 1999PA900035.

Altabet, M. A., M. J. Higginson, and D. W. Murray (2002), The effect of millennial-scale changes in Arabian Sea denitrification on atmospheric $\mathrm{CO}_{2}$, Nature, 415, 159-162, doi:10. 1038/415159a.

Bard, E., F. Rostek, and G. Ménot-Combes (2004), Radiocarbon calibration beyond $20,000{ }^{14} \mathrm{C}$ yr B.P. by means of planktonic foraminifera of the Iberian Margin, Quat. Res., 61, 204-214, doi:10.1016/j.yqres.2003. 11.006.

Berger, R., R. E. Taylor, and W. F. Libby (1966), Radiocarbon content of marine shells from the California and Mexican west coast, Science, 153, 864-866, doi:10.1126/science. 153 . 3738.864

Blunier, T., et al. (1998), Asynchrony of Antarctic and Greenland climate change during the last glacial period, Nature, 394, 739-743, doi: $10.1038 / 29447$.

Brandes, J. A., A. H. Devol, T. Yoshinari, D. A. Jayakumar, and S. W. A. Naqvi (1998), Isotopic composition of nitrate in the central Arabian Sea and eastern tropical North Pacific: A tracer for mixing and nitrogen cycles, Limnol. Oceanogr., 43, 1680-1689

Calvert, S. E., T. F. Pedersen, and R. E. Karlin (2001), Geochemical and isotopic evidence for post-glacial palaeoceanographic changes in Saanich Inlet, British Columbia, Mar. Geol., 174, 287-305, doi:10.1016/S0025-3227(00) 00156-0

Cannariato, K. G., and J. P. Kennett (1999), Climatically related millennial-scale fluctuations in strength of California margin oxygenminimum zone during the past 60 k.y., Geology, 27, 975-978, doi:10.1130/0091-7613(1999) 027<0975:CRMSFI $>2.3 . \mathrm{CO} ; 2$.

Chappellaz, J., et al. (1993), Synchronous changes in atmospheric $\mathrm{Ch} 4$ and Greenland climate between 40 and $8 \mathrm{kyr}$ BP, Nature, 366, 443-445, doi:10.1038/366443a0.

Cline, J. D., and I. R. Kaplan (1975), Isotopic fractionation of dissolved nitrate during denitrification in the eastern tropical North Pacific Ocean, Mar. Chem., 3, 271-299, doi:10.1016/ 0304-4203(75)90009-2.

Crusius, J., T. F. Pedersen, S. E. Calvert, G. L. Cowie, and T. Oba (1999), A 36 kyr geochemical record from the Sea of Japan of organic matter flux variations and changes in intermediate water oxygen concentrations, Paleoceanography, 14, 248-259, doi:10.1029/ 1998PA900023.

De Pol-Holz, R., O. Ulloa, L. Dezileau, J. Kaiser, F. Lamy, and D. Hebbeln (2006), Melting of the Patagonian Ice Sheet and deglacial perturbations of the nitrogen cycle in the eastern South Pacific, Geophys. Res. Lett., 33, L04704, doi:10.1029/2005GL024477.

De Pol-Holz, R., O. Ulloa, F. Lamy, L. Dezileau, P. Sabatier, and D. Hebbeln (2007), Late Quaternary variability of sedimentary nitrogen isotopes in the eastern South Pacific Ocean, Paleoceanography, 22, PA2207, doi:10.1029/ 2006PA001308.

Deutsch, C., D. M. Sigman, R. C. Thunell, A. N. Meckler, and G. H. Haug (2004), Isotopic constraints on glacial/interglacial changes in the oceanic nitrogen budget, Global Biogeochem. Cycles, 18, GB4012, doi:10.1029/ 2003GB002189.

Emmer, E., and R. C. Thunell (2000), Nitrogen isotope variations in Santa Barbara Basin sedi- ments: Implications for denitrification in the eastern tropical North Pacific during the last 50,000 years, Paleoceanography, 15, 377387, doi:10.1029/1999PA000417.

EPICA Community Members (2006), One-toone coupling of glacial climate variability in Greenland and Antarctica, Nature, 444, 195 198, doi:10.1038/nature05301.

Farrell, J. W., T. F. Pedersen, S. E. Calvert, and B. Nielsen (1995), Glacial-interglacial changes in nutrient utilization in the equatorial Pacific Ocean, Nature, 377, 514-517, doi:10.1038/ 377514a0. (Correction, Nature, 378, 216, doi:10.1038/378216a0, 1995.)

Fiedler, P. C. (2002), The annual cycle and biological effects of the Costa Rica Dome, Deep Sea Res., Part I, 49, 321-338, doi:10.1016/ S0967-0637(01)00057-7.

Fiedler, P. C., and L. D. Talley (2006), Hydrography of the eastern tropical Pacific: A review, Prog. Oceanogr., 69, 143-180, doi:10.1016/ j.pocean.2006.03.008

Flückiger, J., A. Dällenbach, T. Blunier, B. Stauffer, T. F. Stocker, D. Raynaud, and J.-M. Barnola (1999), Variations in atmospheric $\mathrm{N}_{2} \mathrm{O}$ concentration during abrupt climatic changes, Science, 285, 227-230, doi:10.1126/science.285.5425. 227.

Flückiger, J., R. Knutti, and J. W. C. White (2006), Oceanic processes as potential trigger and amplifying mechanisms for Heinrich events, Paleoceanography, 21, PA2014, doi:10.1029/2005PA001204.

Ganeshram, R. S., T. F. Pedersen, S. E. Calvert, and J. W. Murray (1995), Large changes in oceanic nutrient inventories from glacial to interglacial periods, Nature, 376, 755-758, doi: $10.1038 / 376755 \mathrm{a} 0$

Ganeshram, R. S., T. F. Pedersen, S. E. Calvert, G. W. McNeill, and M. R. Fontugne (2000), Glacial-interglacial variability in denitrification in the world's oceans: Causes and consequences, Paleoceanography, 15, 361-376, doi:10.1029/1999PA000422.

Grootes, P. M., M. Stuiver, J. W. C. White, S. Johnsen, and J. Jouzel (1993), Comparison of oxygen isotope records from the GISP2 and GRIP Greenland ice cores, Nature, 366, 552554, doi: $10.1038 / 366552 \mathrm{a} 0$.

Gruber, N., and J. L. Sarmiento (1997), Global patterns of marine nitrogen fixation and denitrification, Global Biogeochem. Cycles, 11 235-266, doi:10.1029/97GB00077.

Haug, G. H., K. A. Hughen, D. M. Sigman, L. C. Peterson, and U. Rohl (2001), Southward migration of the intertropical convergence zone through the Holocene, Science, 293, 1304-1308, doi:10.1126/science.1059725.

Hendy, I. L., and J. P. Kennett (2003), Tropical forcing of North Pacific intermediate water distribution during Late Quaternary rapid climate change?, Quat. Sci. Rev., 22, 673-689, doi:10.1016/S0277-3791(02)00186-5.

Hendy, I. L., and T. F. Pedersen (2006), Oxygen minimum zone expansion in the eastern tropical North Pacific during deglaciation, Geophys. Res. Lett., 33, L20602, doi:10.1029/ 2006GL025975.

Hendy, I. L., T. F. Pedersen, J. P. Kennett, and R. Tada (2004), Intermittent existence of a southern Californian upwelling cell during submillennial climate change of the last $60 \mathrm{kyr}$, Paleoceanography, 19, PA3007, doi:10.1029/ 2003PA000965.

Higginson, M. J., and M. A. Altabet (2004), Initial test of the silicic acid leakage hypothesis using sedimentary biomarkers, Geophys. Res. Lett., 31, L18303, doi:10.1029/2004GL020511.
Ivanochko, T. S., and T. F. Pedersen (2004), Determining the influences of Late Quaternary ventilation and productivity variations on Santa Barbara Basin sedimentary oxygenation: A multi-proxy approach, Quat. Sci. Rev., 23 , $467-480$, doi:10.1016/j.quascirev. 2003 . 06.006.

Ivanochko, T. S., et al. (2005), Variations in tropical convection as an amplifier of global climate change at the millennial scale, Earth Planet. Sci. Lett., 235, 302-314, doi:10.1016/ j.epsl.2005.04.002.

Kessler, W. S. (2006), The circulation of the eastern tropical Pacific: A review, Prog. Oceanogr., 69, 181-217, doi:10.1016/j.pocean. 2006.03.009.

Kiefer, T., and M. Kienast (2005), Patterns of deglacial warming in the Pacific Ocean: A review with emphasis on the time interval of Heinrich event 1, Quat. Sci. Rev., 24, $1063-$ 1081, doi:10.1016/j.quascirev.2004.02.021.

Kienast, M., et al. (2006), Eastern Pacific cooling and Atlantic overturning circulation during the last deglaciation, Nature, 443, 846-849, doi:10.1038/nature05222.

Kienast, S. S., S. E. Calvert, and T. F. Pedersen (2002), Nitrogen isotope and productivity variations along the northeast Pacific margin over the last 120 kyr: Surface and subsurface paleoceanography, Paleoceanography, 17(4), 1055, doi:10.1029/2001PA000650.

Koutavas, A., and J. Lynch-Stieglitz (2003), Glacial-interglacial dynamics of the eastern equatorial Pacific cold tongue-Intertropical Convergence Zone system reconstructed from oxygen isotope records, Paleoceanography 18(4), 1089, doi:10.1029/2003PA000894

Koutavas, A., and J. Lynch-Stieglitz (2004), Variability of the marine ITCZ over the eastern Pacific during the past 30,000 years: Regional perspective and global context, in The Hadley Circulation: Present, Past and Future, vol. 21 , edited by H. F. Diaz and R. S. Bradley, 347369, doi:10.1007/978-1-4020-2944-8_12, Springer, Dordrecht, Netherlands.

Koutavas, A., J. Lynch-Stieglitz, T. M. Marchitto Jr., and J. P. Sachs (2002), El Niño-like pattern in ice age tropical Pacific sea surface temperature, Science, 297, 226-230, doi:10.1126/ science. 1072376

Liu, K.-K., and I. R. Kaplan (1989), The eastern tropical Pacific as a source of ${ }^{15} \mathrm{~N}$-enriched nitrate in seawater off southern California Limnol. Oceanogr., 34, 820-830.

Liu, Z., M. A. Altabet, and T. D. Herbert (2005), Glacial-interglacial modulation of eastern tropical North Pacific denitrification over the last 1.8-Myr, Geophys. Res. Lett., 32, L23607, doi:10.1029/2005GL024439.

McElroy, M. B. (1983), Marine biological controls on atmospheric $\mathrm{CO}_{2}$ and climate, Nature, 302, 328-329, doi:10.1038/302328a0

Monnin, E., et al. (2001), Atmospheric $\mathrm{CO}_{2}$ concentrations over the last glacial termination, Science, 291, 112-114, doi:10.1126/science. 291.5501.112.

Mortlock, R. A., and P. N. Froelich (1989), A simple method for the rapid-determination of biogenic opal in pelagic marine-sediments, Deep Sea Res., Part A, 36, 1415-1426.

Naqvi, S. W. A., and D. A. Jayakumar (2000), Ocean biogeochemistry and atmospheric composition: Significance of the Arabian Sea Curr. Sci., 78, 289-299.

Nevison, C., J. H. Butler, and J. W. Elkins (2003), Global distribution of $\mathrm{N}_{2} \mathrm{O}$ and the $\Delta \mathrm{N}_{2} \mathrm{O}-\mathrm{AOU}$ yield in the subsurface ocean, 
Global Biogeochem. Cycles, 17(4), 1119, doi:10.1029/2003GB002068.

Nevison, C. D., T. J. Lueker, and R. F. Weiss (2004), Quantifying the nitrous oxide source from coastal upwelling, Global Biogeochem. Cycles, 18, GB1018, doi:10.1029/2003GB002110.

Petit, J. R., et al. (1999), Climate and atmospheric history of the past 420,000 years from the Vostok ice core, Antarctica, Nature, 399 , 429-436, doi:10.1038/20859.

Pichevin, L., E. Bard, P. Martinez, and I. Billy (2007), Evidence of ventilation changes in the Arabian Sea during the Late Quaternary: Implication for denitrification and nitrous oxide emission, Global Biogeochem. Cycles, 21, GB4008, doi:10.1029/2006GB002852.

Robinson, R. S., A. Mix, and P. Martinez (2007), Southern Ocean control on the extent of denitrification in the southeast Pacific over the last 70 ka, Quat. Sci. Rev., 26, 201-212, doi:10.1016/j.quascirev.2006.08.005.

Schmittner, A., E. D. Galbraith, S. W. Hostetler, T. F. Pedersen, and R. Zhang (2007), Large fluctuations of dissolved oxygen in the Indian and Pacific oceans during Dansgaard-Oeschger oscillations caused by variations of North Atlantic Deep Water subduction, Paleoceanography, 22, PA3207, doi:10.1029/2006PA001384.

Sigman, D. M., et al. (1997), Natural abundancelevel measurement of the nitrogen isotopic composition of oceanic nitrate: An adaptation of the ammonia diffusion method, Mar. Chem., 57, 227-242, doi:10.1016/S03044203(97)00009-1.
Sigman, D. M., R. Robinson, A. N. Knapp, A. van Geen, D. C. McCorkle, J. A. Brandes, and R. C. Thunell (2003), Distinguishing between water column and sedimentary denitrification in the Santa Barbara Basin using the stable isotopes of nitrate, Geochem. Geophys. Geosyst., 4(5), 1040, doi:10.1029/2002GC000384.

Sowers, T., R. B. Alley, and J. Jubenville (2003), Ice core records of atmospheric $\mathrm{N}_{2} \mathrm{O}$ covering the last 106,000 years, Science, 301, 945-948, doi:10.1126/science.1085293.

Spahni, R., et al. (2005), Atmospheric methane and nitrous oxide of the late Pleistocene from Antarctic ice cores, Science, 310, 1317-1321, doi:10.1126/science. 1120132 .

Stott, L. D., W. Berelson, R. Douglas, and D. Gorsline (2000), Increased dissolved oxygen in Pacific intermediate waters due to lower rates of carbon oxidation in sediments, Nature, 407, 367-370, doi: $10.1038 / 35030084$

Stott, L., C. Poulsen, S. Lund, and R. Thunell (2002), Super ENSO and global climate oscillations at millennial time scales, Science, 297. $222-226$, doi:10.1126/science.1071627. (Correction, Science, 298, 751, doi:10.1126/ science.298.5594.751, 2002.)

Suntharalingam, P., J. L. Sarmiento, and J. R. Toggweiler (2000), Global significance of nitrous-oxide production and transport from oceanic low-oxygen zones: A modeling study, Global Biogeochem. Cycles, 14, 1353-1370, doi:10.1029/1999GB900100.

Suthhof, A., V. Ittekkot, and B. Gaye-Haake (2001), Millennial-scale oscillation of denitrification intensity in the Arabian Sea during the
Late Quaternary and its potential influence on atmospheric $\mathrm{N}_{2} \mathrm{O}$ and global climate, Global Biogeochem. Cycles, 15, 637-649, doi:10. 1029/2000GB001337.

Thunell, R. C., and A. B. Kepple (2004), GlacialHolocene $\delta^{15} \mathrm{~N}$ record from the Gulf of Tehuantepec, Mexico: Implications for denitrification in the eastern equatorial Pacific and changes in atmospheric $\mathrm{N}_{2} \mathrm{O}$, Global Biogeochem. Cycles, 18, GB1001, doi:10.1029/ 2002GB002028

Toggweiler, J. R., and S. Carson (1995), What are the upwelling systems contributing to the ocean's carbon and nutrient budgets?, in Upwelling in the Ocean: Modern Processes and Ancient Records, edited by C. P. Summerhayes, pp. 337-360, John Wiley, New York.

Wyrtki, K. (1966), Oceanography of the eastern equatorial Pacific Ocean, Oceanogr. Mar. Biol., 4, 33-68.

E. Arellano-Torres, S. Francavilla, R. S. Ganeshram, and L. E. Pichevin, School of Geosciences, University of Edinburgh, Grant Institute, West Main Road, Edinburgh EH10 3JW, UK. (laetitia.pichevin@ed.ac.uk)

L. Beaufort, CEREGE, Europôle de l'Arbois, BP 80, F-13545 Aix-en-Provence, CEDEX 4, France.

T. F. Pedersen, School of Earth and Ocean Sciences, University of Victoria, PO Box 3065 STN CSC, Victoria, BC V8W 3V6, Canada. 